\title{
THE WELFARE COST OF THE EMU FOR TRANSITION COUNTRIES
}

\author{
Alexandra Ferreira-Lopes*
}

\begin{abstract}
:
The Czech Republic, Hungary, and Poland are set to join the Economic and Monetary Union $(E M U)$ in the near future. This paper offers a framework for the quantitative evaluation of the economic costs of joining the EMU. Using an open economy dynamic general equilibrium model with sticky prices, we investigate the economic implications of the loss of monetary policy flexibility associated with EMU for each of these economies. The main benefit of this general equilibrium approach is that we can directly evaluate the effects of monetary policy in terms of welfare. Our findings suggest that the Czech Republic and Poland may experience sizable welfare costs as a result of joining the EMU. Results for Hungary are less striking as welfare costs in this country seem to be negligible in the benchmark economy. Nevertheless, costs of joining the EMU are higher if government shocks are important and when the trade share with the EMU is small.
\end{abstract}

Keywords: monetary policy, euro, welfare analysis, Czech Republic, Poland, Hungary JEL Classification: C68, E52, F41

\section{Introduction}

Should Poland, Hungary, and the Czech Republic adopt the euro? In this paper we construct a model to evaluate the economic costs of the loss of monetary policy associated with joining the EMU for each of these countries, the largest economies that joined the European Union (EU) in May of 2004. Our focus is on the loss of autonomy of monetary policy and its implications for business cycle synchronization. Business cycle synchronization is an important decision factor for joining the EMU. It is often argued that it is not a good decision to join the euro if a country's economic cycle is not synchronized with that of other members, as a Common Monetary Policy may actually accentuate economic fluctuations.

In this paper we develop a two country dynamic general equilibrium model with sticky prices, so that monetary policy can be used as a short-run policy instrument of economic stabilization. We then investigate the economic implications of the loss of monetary policy flexibility associated with the EMU for each of the three countries. Specifically, we consider two different scenarios: (1) one in which the country is currently inside

* ISCTE Business School - University Institute of Lisbon, Economic Department, Lisboa, Portugal (alexandra.ferreira.lopes@iscte.pt). 
the EMU and therefore the monetary policy rule is established by the European Central Bank (ECB), which follows a weighted Taylor Rule, designated Common Monetary Policy; (2) another where the country is outside the EMU and therefore the monetary policy is established by the country's central bank, which follows a Taylor Rule, designated Autonomous Monetary Policy. We then examine the macroeconomic implications of these two policy arrangements and offer a detailed welfare analysis to formally assess which is preferred by domestic residents.

In order to undertake a welfare analysis to evaluate different monetary policy regimes, this work brings together two types of literature: the optimum currency areas literature with seminal work by Mundell (1961), McKinnon (1963), and Kenen (1969) and the dynamic stochastic general equilibrium (DSGE) models literature in the tradition of Obstfeld and Rogoff (1995) and Chari et al. (2002a). ${ }^{1}$ We use this framework to study the decision to join the Economic and Monetary Union in terms of the loss of monetary policy flexibility for the Czech Republic, Hungary, and Poland, calibrating models specifically for each economy; a task we have never encountered in the literature and for the purpose stated above. We also introduce a new interest rate rule for the ECB that accommodates the Eurozone countries' weights, since the countries do not have the same economic weight, and their economic importance will therefore enter into the interest rule of the ECB with different weights. This modification is important because a big country can influence the way the interest rate rule moves if it enters the Eurozone, but a small country does not have this type of influence, and business cycle synchronization becomes more important. Additionally, in the simulation Common Monetary Policy we kept the exchange rate fixed, thereby eliminating also exchange rate volatility.

EMU membership could be a costly decision for Hungary and the Czech Republic in terms of the loss of monetary policy. For the Hungarian economy, results are weaker and it seems that Hungarian consumers are indifferent between the monetary policy of their central bank and the monetary policy of the ECB. A robustness analysis of the results shows that the loss of monetary policy flexibility is more or less costly depending on several factors. The decision to enter is more costly when government shocks are important (for the Czech Republic and Poland), when technological shocks are important (for Hungary), and it also depends on the value of the import share between the countries under study and the EMU. Benefits of joining the EMU, for some countries, can arise from a more active monetary policy and if consumers have a strong preference for present consumption. The cross-country correlation of technological and government consumption shocks is not very important to these countries' decisions. The calculation of some benefits and costs are excluded from our work, but the values found in this work for the costs of the loss of monetary policy flexibility are similar to those reached in other studies when calculating some benefits and other costs, as we discuss in Section 5 (results).

1 See Goodfriend and King (1997), Clarida et al. (1999), and Lane (2002) for surveys on models of monetary policy and new open economy macroeconomics. 
DSGE models with nominal rigidities usually based on the models of Obstfeld and Rogoff (1995) and Chari et al. (2002a), like our own, have been used to study the problem of the loss of independence of monetary policy and exchange rate flexibility when joining monetary unions. When used to study the costs in terms of stabilization and welfare of joining a currency union, the class of models mentioned reveals that countries face a trade-off upon joining between greater instability in output and lower instability in inflation, and that this trade-off improves with the degree of cross-country symmetry of supply and demand shocks. These findings lead to the conclusion that maintaining the monetary stabilization possibility always proves to be welfare improving, regardless of the changes in the correlation and type of shocks (Monacelli, 2000). The author found these results with a general calibration (not specific to any country). Carré and Collard (2003) apply the model to the French economy to assess the consequences on individual welfare of the loss of exchange rate flexibility when facing asymmetric shocks, finding that in the presence of asymmetric permanent shocks to either technology or government expenditures, it is beneficial to households in the country hit by an asymmetric shock to join a monetary union. Corsetti (2008) studies the costs, in theoretical terms, of losing monetary policy independence and exchange rate flexibility in the light of optimum currency area theory, using a micro-founded choice-theoretic model. The author states that a Common Monetary Policy produces a level of economic activity that is lower than the optimum, but since exchange rates do not present a stabilizing role as stated by the optimum currency area literature, monetary policy can be efficient if the proportion of national goods in the consumption basket of the union is similar to the share of value added in total GDP across countries. Using a theoretical model with no specific calibration, Ca'Zorzi et al. (2012) state that entry is welfare improving the smaller the country, the smaller the correlation of technological shocks between countries, the higher the variance of real exchange rate shocks, the larger the difference between the volatility of technological shocks across Member Countries, and the greater the gain in potential output, compared with the gain in potential output of a flexible exchange rate regime.

For the countries under study in this paper, Holtemöller (2007) calculated an optimum currency area (OCA) index to measure the economic consequences of joining the EMU and uses a Taylor Rule similar to the one we use here in one of the simulations, but in a different economic framework. The OCA index measures the relative loss in terms of output gap and inflation variability in the two regimes stated above. He concludes that both the Czech Republic and Hungary can reduce the volatility of inflation and output gap if they join the monetary union, but results for Poland are inconclusive. The author does not measure welfare in the way we do. Sánchez $(2007,2008)$ studies the role of the nature of the shocks, aggregate and sectoral productivity shocks, in the performance of the Common Monetary Policy in a simple macroeconomic model. The author focuses particularly on the case of catching-up member states, such as the Central and Eastern European Countries (CEECs). Common Monetary Policy performs better than an Autonomous Monetary Policy when countries face an aggregate supply shock, especially when their preferences regarding price stability and their economic size are 
relatively similar. When a country faces sectoral productivity shocks, an Autonomous Monetary Policy is better to stabilize it, especially when it carries Balassa-Samuelson effects on relative prices and real exchange rates. When a currency union can include transition countries as Members (like the CEECs, which commonly have this last type of effect), the possibility of an asymmetric shock increases. He also finds a positive role of trade openness in diminishing the cost of adopting a common currency, since the influence of foreign prices is greater, as well as a positive influence of the size of the country, since a larger country can have a stronger impact on a Common Monetary Policy. In these two works the author does not calibrate specifically for the CEECs.

Kolasa (2009) calibrates a two-country DSGE model for the Polish economy and the Eurozone to study the importance of heterogeneity and asymmetric shocks. The author finds differences in the volatility and synchronization of the shocks that occur in each of the two economies, which could potentially lead to the conclusion that euro adoption by Poland at this stage would be harmful. However, the degree of heterogeneity found in the shocks of the two economies is similar to that found in some studies that address Eurozone Member States. The previous study assesses the differences in parameter values, but does not make any specific analysis about benefits and costs of Poland joining the EMU, and also does not provide a calculation of welfare. Bruha et al. (2010) calibrate a DSGE model specifically for the Czech Republic and the EU and stress the importance of knowing the long-run trajectories of a transition economy, especially in the case of the Czech Republic, which must join the euro sometime in the future. The model replicates the macroeconomic events that occurred in the Czech Republic in recent years, but it does not focus on the benefits and costs of the Czech Republic joining the EMU. Hurník et al. (2010) use a New-Keynesian DSGE model to analyse the potential costs and benefits, in terms of shocks, of joining the EMU for the Czech Republic. They conclude that inflation volatility probably would increase after entering the EMU and even the disappearance of exchange rate volatility does not offset the increase in inflation volatility.

The difference between our study and those mentioned above for the CEECs is that we calibrate our DSGE model specifically for the three economies - the Czech Republic, Hungary, and Poland - and perform welfare analysis, i.e. we calculate the percentage of consumption that consumers are willing to give up in order to be in an economy in which the central bank is autonomous.

The outline of the paper is as follows. Section 2 presents some initial evidence regarding the three economies under study. In Section 3 we describe the model, while Section 4 describes our methodology and calibration procedures. Section 5 contains our main results and Section 6 examines their robustness. Section 7 concludes.

\section{Empirical Evidence}

In this section we analyse some of the most commonly used indicators of the optimum currency area literature to assess the adequateness of a country to join a currency union. The Czech Republic, Hungary, and Poland are the largest countries joining the EU 
in May 2004 and are scheduled to join the Economic Monetary Union at some time in the future, because unlike the United Kingdom and Denmark, they do not have an opt-out clause.

Hungary's currency is currently free floating and the country has not determined a date for euro adoption, Poland's currency is currently floating. The Czech Republic has not yet set a date for joining the euro.

The current economic conditions of these countries differ from those of Portugal and Greece (the poorest of the European Union economies) at the time of their accession to the EMU, as we can see in Table 1. Relative to the EU-15 countries, GDP per capita in Hungary and Poland is lower than that of Portugal and Greece at the time of EMU accession, but GDP per capita in the Czech Republic is similar. These countries are also small open economies like Portugal and Greece, but much more open to trade. This makes them especially vulnerable to shocks and highly dependent on foreign trade partners. The results for the Czech Republic are in line with the conclusions of the work of the Czech National Bank (2012) concluding that the country has a high degree of openness and the GDP per capita has been converging to the European Union average. Degree of openness is calculated as [(exports + imports)/2]/gdp*100. The variables are in nominal terms.

Table 1

Comparison of GDP per capita and Degree of Openness in the Accession Year

\begin{tabular}{|l|c|c|}
\hline Countries & GDP per capita in PPP (EU-15=100) & Degree of Openness (\%) \\
\hline Greece (2001) & 74.6 & $27.2 \%$ \\
\hline Portugal (1999) & 70.5 & $28.7 \%$ \\
\hline Czech Republic (2012) & 73.5 & $71.3 \%$ \\
\hline Hungary (2012) & 59.4 & $65.1 \%$ \\
\hline Poland (2012) & 60.4 & $38.5 \%$ \\
\hline
\end{tabular}

Source: NewCronos

Business cycle synchronization is also an important decision factor to join the EMU. If business cycles are not synchronized the impact of a Common Monetary Policy is different for each country and may hurt the economy of the country. The ECB considers only the average economic condition of the Eurozone when setting monetary policy. Table 2 shows results for the cross-country correlations between the countries under study and the Eurozone. In Appendix A we provide details on empirical data and methodological issues for these calculations. The superscript * identifies Eurozone variables. Results for Poland (POL) show that the country has a positive correlation with the Eurozone for output (Y) and investment (I), and a negative correlation with labour (1) and consumption (c). We can see that Hungary (HUN) is the country having more variables with a positive correlation with the Eurozone. Synchronization does not exist between the Czech Republic (CZE) and the Eurozone, with correlations for the 
variables being either small ( 0.09 for output) or negative (for consumption, investment, and labour). The analysis of business cycle for these countries must be seen with caution since these economies are still on their transition paths.

Table 2

Cross-Country Correlation between the Countries and the EMU

\begin{tabular}{|l|c|c|c|}
\hline & CZE & HUN & POL \\
\hline$\left(Y, Y^{*}\right)$ & 0.09 & 0.23 & 0.35 \\
\hline$\left(c, c^{*}\right)$ & -0.44 & 0.02 & -0.24 \\
\hline$\left(I, I^{*}\right)$ & -0.33 & 0.26 & 0.51 \\
\hline$\left(l, l^{*}\right)$ & -0.22 & 0.62 & -0.12 \\
\hline
\end{tabular}

Other studies have focused on business cycle synchronization between these countries and the Eurozone. Based on supply and demand shock correlations between these countries and the Eurozone, Fidrmuc and Korhonen (2003) conclude that EMU accession would be easy for Hungary, and have mixed results for Poland and the Czech Republic. Furceri and Karras (2006) analyse some potential macroeconomic costs and benefits of joining the EMU for the New Member Countries, and also for candidate countries. They find, like Fidrmuc and Korhonen (2003), that business cycle synchronization between Hungary and the euro area is high, and also that considering other indicators, accession would be easy for this country. Accession would also be easy for Poland, but difficult for the Czech Republic. Levasseur (2008) finds that using recent data to study business cycle synchronization leads to results contradicting those of Fidrmuc and Korhonen (2003), namely that in recent years Poland seems more suitable for joining the EMU and Hungary less so.

Also important is the proportion of the economic cycle of each country that is explained by an idiosyncratic component vis-à-vis a common component with the Eurozone. If the idiosyncratic component is very high, it could be a problem for EMU accession, because the lower the correlation between the economic cycle of a country and the Eurozone, the greater could be the welfare loss of giving up monetary policy. For the sake of comparison we also present results regarding the common component with the USA. Results for the countries under study are shown in Table 3 and details on the estimations are in Appendix B. 
Table 3

$\%$ of the Variability of the Specific Component in the Total Variability of the Cycle

\begin{tabular}{|l|c|c|}
\hline \multirow{2}{*}{} & \multicolumn{2}{|c|}{$1991-2007$} \\
\cline { 2 - 3 } & Eurozone & USA \\
\hline Czech Republic & $42 \%$ & $47 \%$ \\
\hline Polangary & $29 \%$ & $34 \%$ \\
\hline
\end{tabular}

As we can see, the weight of the specific component is less than $50 \%$ in the three transition countries, especially in Hungary and Poland. The proportion of the specific component is greater when we calculate for the USA, meaning that the proportion of the economic cycle explained by the Eurozone economic cycle is greater. If we take these results into account, it seems, contrary to the other business cycle results, that entering the EMU would be easy for these countries, especially for Hungary and Poland. Results for the Czech Republic are also in line with those of the Czech National Bank (2012) concluding that while business cycle synchronization between the Czech Republic and the EMU has been (slowly) increasing, there is still a high probability that asymmetric shocks will occur, and the country may not be ready to cope with these shocks inside the EMU, since the Eurozone's macroeconomic policies and possible transmission mechanisms and effects may not be appropriate for the country.

\section{Model}

We developed a two-country dynamic equilibrium model in the tradition of Chari et al. (2002a), but modified it to take into account an interest rate rule similar to that suggested by Taylor (1993), which also allows for forward-looking behaviour. We can thereby construct a detailed quantitative analysis for the behaviour of the main macroeconomic variables and, more importantly, quantify the welfare gain associated with the various policy choices. We provide a framework to evaluate the economic costs of EMU membership, namely, to investigate the economic implications of the loss of the monetary policy flexibility that comes with joining the EMU and to assess the effects of monetary policy on welfare.

The home country is represented by $H$ and the foreign country by $F$, which will be regarded as the Eurozone. The benchmark model of Chari et al. (2002a) can be found in Appendix C. In this section we address only our new theoretical contribution to the literature and equilibrium conditions for the model, our hypotheses for decisions of economic agents, and the procedure to solve the model.

\subsection{Government}

New money balances of the home currency are distributed to consumers in the home country in a lump-sum fashion by having transfers satisfy: 


$$
P_{t} g_{t}+T_{t}=M_{t}-M_{t-1}
$$

This equation represents the home government budget constraint, where $P_{t}$ is the price of the final good, $g_{t}$ is government consumption, $T_{t}$ are transfers of home currency, and $M_{t}$ is money.

Several empirical studies have shown that the Taylor rule seems to accurately replicate the monetary policy rule of central banks throughout the world, e.g. Taylor (1993). For our benchmark case we assume that the central bank of country $H$ uses a forward-looking Taylor type interest rate rule formulated by Clarida et al. (2000), represented by:

$$
r_{t}^{N}=\rho^{r} r_{t-1}^{N}+\left(1-\rho^{r}\right)\left[\rho^{\pi} E_{t} \pi_{t+1}+\rho^{0} O_{t}\right]+\varepsilon_{t}^{r^{N}}
$$

where $r_{t}^{N}$ is the nominal interest rate in period $t$ for the domestic economy, $\left(\pi_{t+1}=\frac{P_{t+1}}{P_{t}}-1\right)$ is the inflation rate between period $t$ and $t+1$ for the domestic economy, and $O_{t}{ }^{*}$ is the real gross domestic product at $t$ of the domestic economy. $\varepsilon_{t}^{r^{N}}$ are shocks with a normal distribution, zero average, $\sigma^{r^{N}}$ standard deviation, and positive cross-country correlation. If $\rho^{r}>0$ the rule exhibits some degree of inertia, as the central bank does not fully adjust to current changes in the economy.

Interest rates in country $F$, the Eurozone, are set according to the following new rule that accommodates the Eurozone countries' weights in the rule of the ECB:

$$
r_{t}^{N^{*}}=\rho^{r} r_{t-1}^{N^{*}}+\left(1-\rho^{r}\right)\left[\varpi \rho^{\pi} E_{t} \pi_{t+1}+(1-\varpi) \rho^{\pi} E_{t} \pi_{t+1}^{*}+\varpi \rho^{0} O_{t}+(1-\varpi) \rho^{0} O_{t}^{*}\right]+\varepsilon_{t}^{r^{N^{*}}}
$$

where $\varpi$ is the weight of the home country's GDP in the Eurozone (in simulation Common Monetary Policy), considering that the country is already a Member. For the benchmark case, which we will explain in Section 5, when the home country is outside the Eurozone (simulation Autonomous Monetary Policy), we set $\varpi=0 . r_{t}^{N^{*}}$ is the nominal interest rate in period $t$ for the foreign economy, $\left(\pi_{t+1}^{*}=\frac{P_{t+1}^{*}}{P_{t}^{*}}-1\right)$ is the inflation rate between period $t$ and $t+1$ for the Eurozone, and $O_{t}^{*}$ is the real gross domestic product at $t$ of the Eurozone. As usual, we allow for monetary policy shocks $\varepsilon_{t}^{r^{N^{*}}}$ with a normal distribution, zero average, $\sigma^{r^{N^{*}}}$ standard deviation, and no cross-country correlation. When we use the Taylor rule of the ECB as the policy rule, the domestic economy has no monetary policy shock; we therefore impose the following restriction on the nominal interest rate:

$$
r_{t}^{N}=r_{t}^{N^{*}}
$$




\subsection{Equilibrium Conditions}

All maximization problems for country $F$ are analogous to those of country $H$, as well as market-clearing conditions. An equilibrium requires several market-clearing conditions. The resource constraint in the home country is given by:

$$
y_{t}=c_{t}+g_{t}+\int_{0}^{1} I_{i, t} d i
$$

Where $y_{t}$ is the real final good, $c_{t}$ is real consumption, and $I_{t}$ is real investment.

The labour $\left(l_{t}\right)$ market-clearing condition is:

$$
l_{t}=\int l_{i, t} d i
$$

The market-clearing condition for the sum of contingent bonds of the domestic $\left(B_{t}\right)$ and the foreign economy $\left(B_{t}{ }^{*}\right)$ is:

$$
B_{t}+B_{t}^{*}=0
$$

The state of the economy when monopolists make their pricing decisions (prior to period $t$ ) must record the capital stocks for a representative monopolist in each group in the two countries, the prices set by the other $N-1$ groups in both countries, the period $t-1$ monetary shock but not period $t$ monetary shock, and period $t$ and $t-1$ technological and government consumption shocks. Period $t-1$ shocks help forecast the shocks in period $t$ and current shocks are included in the state of the economy when the remaining decisions are taken. Consumers and final good producers know current and past realizations of shocks. Monopolists know the past and current realizations of technological and government consumption shocks, but know only past realizations of monetary shocks.

We use the Blanchard and Kahn (1980) approach to solve the model. Several procedures are necessary: First, in order to make economies stationary we deflate all first-order conditions of the nominal variables by the growth rate of prices $(m u)$; second, we derive the steady-state equations and conditions for some stationary variables; third, we apply logs and linearize the first-order conditions around the steady state; and finally, we solve the system of equations. ${ }^{2}$

\section{Calibration and Data}

The calibration of the models is made in order to reproduce the long-term properties of the Czech, Hungarian, and Polish economies. In this case, in which the economies under study are transition countries, calibration is difficult. We use the calibration methodology suggested by Prescott (1986) and Cooley (1995). When needed, X12-ARIMA was used to remove seasonality and the Hodrick-Prescott filter to detrend

2 The growth rate of prices $m u$ is calculated in order to respect the observed inflation rates of the countries under study. 
the data. Results for the parameters for each of the three economies are reported in Table 4, at the end of this section.

\subsection{Preferences}

The functional form of the utility function, represented in Appendix C, equation (20), is:

$$
U\left(c, l, \frac{M}{P}\right)=\frac{\left[\frac{c^{(1-\kappa)}}{1-\kappa}+\frac{w\left(\frac{M}{P}\right)^{\frac{\eta-1}{\eta}}}{\frac{\eta-1}{\eta}}+\phi \frac{(1-l)^{(1-\gamma)}}{1-\gamma}\right]^{1-\sigma}}{1-\sigma}
$$

The discount factor $\left(\beta=\left(1 /\left(1+r^{L T}\right)\right)\right)$ is calculated using annual data, 1999-2007 for Poland and Hungary and 2000-2007 for the Czech Republic, later turned into quarterly values, from AMECO, a European Commission annual database. $r^{L T}$ is the real long-term interest rate for government bond yields, which was deflated using the consumer price index. The value for $\sigma$ is 0.0001 for all countries and $\kappa$ is the relative risk aversion coefficient. In order to have a balanced growth we impose $\gamma=\sigma$. The weight on leisure, $\varphi$, is calculated in order to make the time that families dedicate to work equal to a value that matches estimates from the Labour Force Survey of EUROSTAT, for the period between 1997 and 2007.

Parameters concerning real money demand are estimated according to the first-order condition for a nominal bond, which costs one euro at $t$ and pays $\left(1+r^{N}\right)$ euros at $t+1$ :

$$
\log \frac{M_{t}}{P_{t}}=-\eta \log \frac{w}{1-w}+\log c_{t}-\eta \log \left(\frac{r^{N}}{1+r^{N}}\right)
$$

We estimated regressions with quarterly data for the period 1995:01-2005:03, where $M_{1}$ is used for money, the GDP deflator for $P$, private consumption at constant prices for $c$, and the three month interest rate of the money market for $r^{N}$. In the estimation we obtained the value for $\eta$, the interest elasticity of real money demand, and the value for $w$ is residual, which we set equal for all countries.

\subsection{Technology}

\subsubsection{Final Goods Producers}

The elasticity of substitution between home and foreign goods (in equation (21) of Appendix C) is defined as $\left(\frac{1}{1-\rho}\right)$. Some studies, e.g. Whalley (1985), found this elasticity to range between 1 and 2, and was lower for Japan and Europe than for the USA. 
We found the value for this elasticity by calculating the following regression, based on the first-order condition of the demand functions for the intermediate goods:

$$
\log \frac{I M P}{D}=b_{0}+b_{1} \log \frac{P D}{P I M P}+b_{2} \log Y
$$

where $I M P, D$, and $Y$ are respectively imports, national production subtracted from exports, and national income, all at constant prices, $P I M P$ is the imports deflator, $P D$ is the deflator for $D$. We use annual National Accounts data for 1990-2007, 1991-2007, and 1992-2007, respectively for the Czech Republic, Hungary, and Poland.

For the $a_{1}$ and $a_{2}$ parameters, representing respectively the weights of domestic and imported goods, we used annual bilateral trade data from the CHELEM data base for 1990-2006, except for the Czech Republic, where data begin in 1993. Shares for each country are calculated assuming that there are only two countries in the world, each of the transition countries and the Eurozone. $y_{h}$ and $y_{f}$ represent the share of imports from the Eurozone as a percentage of GDP and the share of national production as a percentage of GDP, respectively. To calculate $a_{1}$ and $a_{2}$ in their steady-state values, the following relationship is used: $y_{h} / y_{f}=\left[a_{1} / a_{2}\right]^{\frac{1}{1-\rho}}$.

\subsubsection{Intermediate Goods Producers}

The production function for intermediate producers, represented in Section 10.3 of Appendix C, is a Cobb-Douglas with constant returns to scale:

$$
F(k, A l)=k^{\alpha}(A l)^{1-\alpha}
$$

where $k$ is the capital stock. We calculated the share of capital, $\alpha$, using OECD statistics for the capital income share of the private sector for the Czech Republic. We assume that Hungary has the same capital share as the Czech Republic, because we did not find available data for the former country. For Poland the value was taken from Zienkowski (2000).

For the mark-up parameter we use data between 1992 and 2006, 1991 and 2005, and 1995 and 2006, respectively for the Czech Republic, Hungary, and Poland, taken from the NewCronos data base. In order to calculate the value for the mark-up parameter, we need to define several variables. First, we define the mark-up of price to marginal cost as $P_{H} / P_{v}=1 / \theta$. We then need to define profit as $\Pi=y$-vy, where $v$ is the real unit cost. In steady state $v=\theta$, and as a result, $\Pi / y=1-\theta$. To obtain an estimate of $\Pi / y$, we follow Domowitz et al. (1986) and define the price-cost margin as (value added-payroll)/ (value added + cost of materials). In the steady state of the model the numerator of the former equation equals $\Pi+(r+\delta) k$, in which $\delta$ is the depreciation rate of capital. We calculate the denominator as Jorgenson et al. (1987), assuming that the value for the cost of materials is similar to the value added. We then calculate the steady-state values for $r+\delta$ and $k / y$. The previous calculations imply the value for $\Pi / y$. Using the last value, we find the mark-up, which implies the value for $\theta$. 
We choose the number of periods that prices remain fixed for all countries and for each group of producers, based on Gali et al.'s (2001) estimates, in which the number of quarters that prices stay fixed in Europe is about six periods.

\section{Capital Accumulation}

We could not find data for the capital stock of these countries, so we use data for the capital stock and gross fixed capital formation (GFCF) for the Eurozone taken from AMECO, for the 1991-2007 period, and we assume that the steady states for these economies will be close to the Eurozone value. The depreciation rate for capital was calculated implicitly by the following formula:

$$
k_{t}=(1-\delta) k_{t-1}+I_{t}
$$

\section{Adjustment Costs}

The adjustment cost function has the following expression:

$$
\varphi\left(\frac{I}{k}\right)=\left(\frac{I}{k}-\delta\right) / 2
$$

The function is convex and satisfies the conditions $f(\delta)=0$ and $f^{\prime}(\delta)=0$, implying that total and marginal costs of adjustment in the steady state are zero. $b$ is the adjustment costs parameter.

\subsection{Shocks}

\subsubsection{Technological Shocks}

The technological shocks $A_{t}$ and $A_{t}{ }^{*}$ are common to all intermediate goods producers of each country, following a stochastic process:

$$
\log A_{t+1}=\rho^{A} \log A_{t}+\varepsilon_{t+1}^{A}
$$

and

$$
\log A_{t+1}^{*}=\rho^{A} \log A_{t}^{*}+\varepsilon_{t+1}^{A^{*}}
$$

where technological innovations $\varepsilon^{A}$ and $\varepsilon^{4^{*}}$ have a normal distribution, with zero mean, $\sigma^{A}$ standard deviation, and are cross-country correlated but are not correlated with the monetary and government consumption shocks. We estimate a VAR[1] for each of the three economies and the Eurozone for the period between 1995:01-2007:04. ${ }^{3}$

3 Solow residuals were estimated using labour data only, because quarterly data for the capital stock is not available for these countries. 


\subsubsection{Government Consumption Shocks}

Government consumption shocks are modelled as stochastic processes, with the following expressions:

$$
\log g_{t+1}=\left(1-\rho^{g}\right) \mu^{g}+\rho^{g} \log g_{t}+\varepsilon_{t+1}^{g}
$$

and

$$
\log g_{t+1}^{*}=\left(1-\rho^{g}\right) \mu^{g}+\rho^{g} \log g_{t}^{*}+\varepsilon_{t+1}^{g^{*}}
$$

where government shocks $\varepsilon^{g}$ and $\varepsilon^{g^{*}}$ have a normal distribution, with $\mu^{g}$ mean, and $\sigma^{g}$ standard deviation. These shocks are not correlated with monetary shocks, with technological shocks, or with the foreign government consumption shocks. We use quarterly data from the EUROSTAT National Accounts for the period between 1995:01-2007:04 to estimate the parameters.

\subsubsection{Monetary Policy Shocks}

In this model the national central bank follows a Taylor Rule, represented in equation (2). For all three countries the rule of the national central bank exhibits a positive correlation of 0.1 with the foreign monetary policy rule. We assume this since countries (although outside the Eurozone) are hit by common shocks, and monetary policy rules therefore usually can have some degree of correlation.

The policy rule of the ECB is characterized by equation (3). For this institution the parameters for $\rho_{r}, \rho_{\pi}$, and $\rho_{O}$ are $0.85,1.48$, and 0.60 , respectively. The volatilities of the shocks to this rule differ between simulations for each country; these are $0.679 \%$, $0.338 \%$, and $0.605 \%$ for the Czech Republic, Hungary, and Poland, respectively. In the same order, their economic weights, $\varpi$, are $1.1 \%, 0.9 \%$, and $3.1 \%$. We kept a fixed exchange rate in the simulation in which the ECB is in charge of monetary policy, calibrating with the most recent values for the nominal exchange rate. Policy rules for the Czech Republic, Hungary, and Poland were based on Angeloni et al. (2005). We loosely assume that all three countries have a floating exchange rate, since Hungarian and Polish currencies fluctuate, and the Czech Republic has a managed float. The Taylor Rule of the ECB was taken from Hayo and Hoffman (2006).

The variances of the three shocks were calculated in order to reproduce the volatility of output close to empirical data.

\subsection{Summary}

Calibration for these countries exhibit some differences that are worth noting, as we can see in Table 4; in Hungary technological shocks are more persistent than in the other two countries, although Poland shows positive cross-country correlations. The value 
of the elasticity of substitution between domestic and imported goods for Poland is much higher than in the other two countries. The Czech Republic is the country where people spend most time working. The Taylor Rule of Hungary in Autonomous Monetary Policy simulation is smoother than in the other two countries. These differences influence the results and play an important role in the decision process to join (or not) the EMU.

Table 4

Calibration Values for the Three Countries under Study

\begin{tabular}{|c|c|c|c|}
\hline & CZE & HUN & POL \\
\hline \multicolumn{4}{|c|}{ Preferences } \\
\hline$\beta$ & 0.995 & 0.996 & 0.991 \\
\hline$\phi$ & 335 & 245 & 319 \\
\hline$\eta$ & -0.222 & -0.100 & -0.299 \\
\hline$\kappa$ & 3.52 & 2.73 & 3.51 \\
\hline \multicolumn{4}{|c|}{ Final Good Technology } \\
\hline$\rho$ & 0.346 & 0.265 & 0.691 \\
\hline$a_{1}$ & 0.635 & 0.672 & 0.634 \\
\hline$a_{2}$ & 0.365 & 0.328 & 0.366 \\
\hline \multicolumn{4}{|c|}{ Intermediate Good Technology } \\
\hline$\alpha$ & 0.385 & 0.385 & 0.400 \\
\hline$\delta$ & $1.18 \%$ & $1.18 \%$ & $1.18 \%$ \\
\hline$\theta$ & 0.915 & 0.922 & 0.938 \\
\hline$b$ & 48 & 46 & 29 \\
\hline \multicolumn{4}{|c|}{ Taylor Rule National Bank } \\
\hline$\rho^{r}$ & 0.90 & 0.95 & 0.90 \\
\hline$\rho^{\pi}$ & 1.27 & 1.18 & 1.18 \\
\hline$\rho^{\circ}$ & 0.11 & 0.50 & 0.79 \\
\hline$\sigma^{r}$ & 0.004 & 0.002 & 0.006 \\
\hline \multicolumn{4}{|c|}{ Technological Shocks } \\
\hline$\rho^{A}$ & 0.376 & 0.826 & 0.530 \\
\hline$\sigma^{A}$ & 0.005 & 0.012 & 0.010 \\
\hline $\operatorname{corr}\left(\varepsilon^{A}, \varepsilon^{A^{*}}\right)$ & 0.017 & 0.178 & 0.422 \\
\hline \multicolumn{4}{|c|}{ Government Consumption Shocks } \\
\hline$\rho^{g}$ & 0.972 & 0.983 & 0.981 \\
\hline$\sigma^{g}$ & 0.005 & 0.012 & 0.010 \\
\hline$\mu^{g}$ & 0.119 & 0.138 & 0.110 \\
\hline
\end{tabular}




\section{Results}

\subsection{Methodology}

The main purpose of this work is to formally analyse the consequences of different rules for monetary policy in terms of consumer welfare in the three countries. We therefore ask how much consumption consumers are willing to give (or receive) in order to remain indifferent between the Common Monetary Policy and the Autonomous Monetary Policy regimes. This corresponds to calculating the compensating variation associated with the full elimination of the Autonomous Monetary Policy regime. The welfare analysis follows the Lucas (1987) method.

A simulation of 1,000 periods was made in both regimes. In the Common Monetary Policy regime technological and government consumption shocks take place in both the domestic and foreign economy, whereas monetary shocks occur only in the foreign economy, representing the Eurozone. In the Autonomous Monetary Policy regime, both economies suffered all three shocks. Based on the simulated time series we calculate the average value of the utility function for both regimes. Given the average values, we calculated the compensating variation in terms of consumption in the following way:

$$
U_{0}\left(\lambda c_{0}, l_{0}, M / P_{0}\right)=U_{1}\left(c_{1}, l_{1}, M / P_{1}\right)
$$

where $U_{0}$ uses the values for $c, l$, and $M / P$ of the Common Monetary Policy regime and $U_{1}$ uses the values of the Autonomous Monetary Policy regime. The value of $\lambda$ represents the gains (or losses) of welfare in terms of consumption percentage.

The goal of this section is to analyse the behaviour of these three economies in the presence of shocks, but we also check to see if the model can replicate some of the main features of business cycle stylized facts. We first analyse the results for business cycles statistics of the simulated economies in the two monetary regimes. Tables A1 to A3 in Appendix A present the results in the third and fourth column of the statistics for the Common Monetary Policy and Autonomous Monetary Policy simulations, respectively, for the domestic economy.

Variables are more volatile in the Autonomous Monetary Policy simulation for all three countries, where there are not only government consumption and technological shocks, but also the monetary policy shock in the domestic economy. In the Common Monetary Policy simulation there are no monetary policy shocks in the domestic economy, since monetary policy is established by the European Central Bank, and volatility is lower in this simulation, as a result. Additionally, exchange rates are fixed in this simulation, which also contributes to a lower volatility. In addition, when we impose equation (4) the volatility of variables decreases. Simulation Autonomous Monetary Policy yields, on average, volatilities more similar to the data than the other simulation. 
Although comparisons of the behaviour of autocorrelations differ from country to country and depend on the magnitude of the shocks and the co-movements between them, on average persistence is greater in the Autonomous Monetary Policy simulation. This is logical, since monetary policy is oriented toward the domestic economy, which means that monetary policy stabilizes the economy more, making variables more persistent.

Analysing the cross-country correlations, we find that the Common Monetary Policy simulation has on average the higher cross-country correlations. This occurs also because of the imposition of equation (4). Especially for consumption and investment, these cross-country correlations are very high and seem to dominate the pattern of cross-country correlations. The Autonomous Monetary Policy simulation yields, on average, cross-country correlations that are more similar to the data than the Common Monetary Policy simulation.

\subsection{Welfare Calculations}

The results based on the methodology described are presented in Table 5 and are very similar across countries. Consumers in the Czech Republic and Poland are willing to give up consumption in order to live in an economy where the monetary policy is established by the national central bank. Hungarian consumers prefer, marginally, to enter the Eurozone. ${ }^{4}$

Table 5

Welfare Results for Benchmark Economies

\begin{tabular}{|l|c|c|c|c|c|}
\hline & $c$ & $l$ & $M / P$ & $U$ & $\lambda$ \\
\hline \multicolumn{7}{|c|}{ Czech Republic } \\
\hline Common Monetary Policy & 0.191 & 0.251 & 0.199 & 224.55 & $-0.63 \%$ \\
\hline Autonomous Monetary Policy & 0.191 & 0.250 & 0.197 & 224.76 & \\
\hline \multicolumn{7}{|c|}{ Hungary } \\
\hline Common Monetary Policy & 0.125 & 0.240 & 0.458 & 164.08 & $+0.05 \%$ \\
\hline Autonomous Monetary Policy & 0.125 & 0.240 & 0.457 & 164.02 & \\
\hline \multicolumn{7}{|c|}{ Poland } \\
\hline Common Monetary Policy & 0.188 & 0.237 & 0.099 & 216.02 & $-0.22 \%$ \\
\hline Autonomous Monetary Policy & 0.188 & 0.237 & 0.099 & 216.06 & \\
\hline
\end{tabular}

The nominal interest rate in the Autonomous Monetary Policy regime is on average higher than in the Common Monetary Policy simulation, in accordance with what occurs in these economies, where inflation rates are also higher. Higher interest rates

4 Results are similar to those reported in Lucas (1987: 26) when calculating the costs of economic instability. 
bring about a greater drop in average consumption. Therefore, labour has to rise by less in order to satisfy the increase in consumption and also to satisfy output demand. The behaviour of labour explains why consumers prefer the Autonomous Monetary Policy regime, at least in Poland and in the Czech Republic. Labour in this simulation is on average lower, and as a result there is more leisure and consumers are better off. In Hungary, consumers marginally prefer to join the Eurozone. The Hungarian monetary policy rule proves to be less stabilizing than the interest rate rule of the ECB, since the interest rate smoothing parameter is very high in comparison with the EMU. This means that the interest rate rule in Hungary does not greatly disturb the economy, but cannot perform its stabilizing role. It is enough to increase the response of the inflation parameter of the Hungarian domestic central bank to reverse the results.

Nominal exchange rate stability can be one of the benefits of joining the EMU, since in the Common Monetary Policy simulation volatilities of the price ratio between countries and the real exchange rate are lower than in the Autonomous Monetary Policy simulation. However, as we can see, for these countries the costs of relinquishing monetary policy are higher, except for the case of Hungary. In the Autonomous Monetary Policy simulation for the Hungarian economy the volatility of the price ratio is well above the values found for the other two economies, once again re-enforcing the weaker stabilization role of the interest rate rule for this economy.

Results are also in agreement with some of the empirical evidence of Section 2. Idiosyncratic shocks in Hungary have a weaker role than those of the Czech Republic and Poland. If a country has a smaller specific component of a given shock, costs of entering a common currency and monetary policy area and relinquishing its monetary policy are obviously lower. Also, cross-country correlations between Hungary and the Eurozone are the highest of the three countries under study, meaning that business cycle synchronization, an important feature to be taken into account in the decision about joining the EMU, is high. The empirical evidence also explains part of the results for the Czech Republic, since the proportion of idiosyncratic shocks is higher and business cycle synchronization is low.

The main differences between simulations within each country are the volatility of the monetary policy shocks, the parameters of the Taylor rules, and the difference between who runs the monetary policy (i.e. Taylor Rule, with or without economic weights). The different welfare results for each country are obviously explained by different parameters, but most importantly by differences regarding the magnitude of technological, government consumption, and monetary policy shocks. In the next section we analyse and discuss some of these parameters. 


\section{Robustness}

We now analyse the robustness of the model in terms of the benchmark welfare value $(\lambda)$ computed above. For simplicity we restrict our discussion to the most significant parameters in the model..$^{5}$ All simulations follow the procedure described earlier. Table 6 summarizes the results for each of the three transition countries. These results reinforce the decisions of Poland and the Czech Republic not to join the Eurozone, at least in the near future. Results for Hungary are less clear cut.

Table 6

Results for Sensitivity Analysis

\begin{tabular}{|c|c|c|}
\hline CZE & HUN & POL \\
\hline \multicolumn{3}{|c|}{ Benchmark } \\
\hline$-0.63 \%$ & $+0.05 \%$ & $-0.22 \%$ \\
\hline \multicolumn{3}{|c|}{ No Technological Shocks } \\
\hline$-0.63 \%$ & $-0.15 \%$ & $-0.22 \%$ \\
\hline \multicolumn{3}{|c|}{ No Government Consumption Shocks } \\
\hline$-0.43 \%$ & $+0.02 \%$ & $-0.11 \%$ \\
\hline \multicolumn{3}{|c|}{ Same Volatility for Taylor Rules } \\
\hline$-1.91 \%$ & $-0.27 \%$ & $-0.23 \%$ \\
\hline \multicolumn{3}{|c|}{ Weight of imported goods from the Eurozone } \\
\hline$-0.84 \%$ & $-0.23 \%$ & $-0.28 \%$ \\
\hline \multicolumn{3}{|c|}{ Increase in Risk Aversion } \\
\hline$+0.12 \%$ & $-0.60 \%$ & $-0.22 \%$ \\
\hline \multicolumn{3}{|c|}{ Higher Correlation of Technological Shocks } \\
\hline$-0.63 \%$ & $+0.04 \%$ & $-0.22 \%$ \\
\hline \multicolumn{3}{|c|}{ Correlation for Government Consumption Shocks } \\
\hline$-0.64 \%$ & $+0.07 \%$ & $-0.26 \%$ \\
\hline
\end{tabular}

Generally, we find that changes in the values of the import share and government consumption shocks seem to have the greatest impact in the change of the welfare value.

Technological shocks do not greatly change the results for these countries, except in the case of Hungary, where they are significantly more persistent. It seems that the Taylor rule of the ECB stabilizes more technological shocks for the Hungarian economy than the monetary policy rule of the domestic economy, and in fact the output parameter

5 We increase the correlations of monetary policy shocks to 0.5 , increase the relative risk aversion coefficient by $25 \%$, and decrease the weight of imported goods from the Eurozone to $25 \%$ below its initial value. We also double the initial cross-country correlation of technological shocks and government consumption shocks now have a positive cross-country correlation of 0.5 . 
of the Taylor rule of the ECB is higher than that of the Hungarian central bank. When technological shocks are removed consumption rises by more, but labour also rises by more in order to compensate for the excess demand, since the income effect prevails. Utility thus falls in the Common Monetary Policy simulation. In the other simulation, since the output parameter does not react greatly to the technological shock, utility is constant. Regarding the increase in the cross-country correlation of technological shocks, results for Czech Republic and Poland do not change, while for Hungary the benefits from entering the EMU decrease very slightly, as in the previous simulation. The persistence of the technological shock is lower in the Czech Republic and Poland.

When we remove government consumption shocks from both simulations, results for Hungary are negligible, but for Poland and the Czech Republic are strong. The need to stabilize idiosyncratic domestic spending shocks disappears, making consumers more willing to join the EMU. Due to its weak inflation parameter in the domestic central bank, Hungary again needs the more aggressive monetary policy rule of the ECB to control domestic shocks. We tested for a more aggressive inflation parameter in the Hungarian central bank and results reverse, i.e. in the absence of a domestic shock, consumers in Hungary prefer to join the Eurozone, as in the other two countries. Results for the simulation in which there is a positive cross-country correlation of government consumption shocks are very similar to the benchmark, and opposite to those of the previous simulation. The Czech Republic and Poland prefer slightly more to stay out of the Eurozone but Hungary prefers slightly more to enter the Eurozone. The reason is the same as mentioned earlier, and has to do with the strength of the parameters in the Taylor rule and the need to stabilize the economy.

In these economies the non-systematic shock introduced in the monetary policy rule of the domestic central bank always has a lower volatility than the non-systematic shock introduced in the monetary policy rule of the ECB. When we increase the volatility of the first rules in order to match the volatility of the ECB, these three countries have an even greater incentive to stay out of the Eurozone. In Table 4 we see that the interest rate smoothing parameter is always higher in the monetary policy rule of the domestic central bank. This means that intervention by each one of these central banks is not done quickly, but that the intervention also does not introduce volatility in the economy. However, since these economies do not have a very high value for the inflation parameter, but do have high inflation rates (higher than those observed in the Eurozone), some volatility of the monetary policy shock is needed in order for monetary policy to have an effect. We perform another simulation in which these three countries have a lower interest rate smoothing parameter (equal to that of the ECB) and results are the opposite, since now they are able to stabilize the economy more and they do not need extra volatility.

For these countries we find that decreases in trade volume with the Eurozone increase the costs of adopting a Common Monetary Policy. This finding is consistent with the theory of the endogeneity of optimum currency areas (Frankel and Rose, 1998). A low trade 
volume increases the domestic economies' exposure to idiosyncratic shocks and makes a Common Monetary Policy less desirable.

Increasing the relative risk aversion coefficient increases the preferences of consumers for present consumption. So, consumers will prefer a regime in which interest rates are lower in order to have higher consumption, but without causing labour or volatility to increase by much. This occurs in the Eurozone, where interest rates are lower than in the three transition countries. The impact of this change also depends on the discount factor $\beta$, since a high discount factor reveals a preference for present consumption.

Additionally, we compare our results to those reported in the literature regarding other costs and benefits of joining the EMU. One of the most important benefits of joining the EMU is the elimination of transaction costs, which should encourage international trade. Rose (2000) found that eliminating multiple currencies in favour of just one, i.e. a common currency area, can increase trade by a factor of nearly three. As with the loss of monetary policy independence, these costs are dynamic and exist as long as transactions occur between countries. For transition countries there are already some studies that assess the benefits of this elimination. For Poland, Wojcik (2000) found that the country could gain $0.1 \%$ of GDP every year by eliminating transaction costs. Estimates for this benefit from the National Bank of Poland (2004) reached a value of $0.2 \%$ of GDP per year. The National Bank of Hungary calculated a value for Hungary of between 0.18 and $0.3 \%$ of GDP (Csajbók and Csermely, eds., 2002). In countries that have a poorly developed financial system, the gains from eliminating transaction costs are higher, since they have fewer financial products with which to defend themselves from exchange rate risk. In our Common Monetary Policy simulation the exchange rate was fixed, by which we also partially capture the benefit of reducing exchange rate volatility.

There are additional benefits and costs of joining a currency union that can be quantified. Regarding benefits, we note the existence of efficiency gains and benefits regarding price stabilization. Brouwer et al. (2008) state that the trade and foreign direct investment (FDI) for Central and Eastern European countries of joining the euro would be positive, being smaller for Poland and larger for Hungary. The National Bank of Hungary calculates the benefit of the expansion of trade in the long run to be around $0.55-0.76$ of GDP for Hungary (Csajbók, Csermely, eds., 2002). Wójcik (2000) calculates the benefit of eliminating exchange rate variability to be (one-time benefit) between $1.4 \%$ and $5.4 \%$ of Poland's GDP. Regarding costs, one quantifiable cost is the loss of seigniorage revenue. Estimates for Hungary place the annual loss of seigniorage revenues between 0.17 and 0.23 of GDP (Csajbók, Csermely, eds., 2002).

Converting our benchmark results to percentage of GDP, we find that in Poland and the Czech Republic, consumers are willing to give up between 0.1 and $0.3 \%$ of their consumption as a percentage of GDP to live in an economy with an autonomous central bank. These results are similar to the benefit of eliminating transaction costs or the loss of seigniorage revenues in the case of Hungary. 


\section{Conclusions}

Although convergence is moving at a brisk pace in the three transition economies, some flexibility regarding monetary policy is needed in order to accommodate shocks, especially in the Czech Republic and Poland. As a result, on average EMU membership can be a costly decision for these two countries in terms of the loss of monetary policy. These results were obtained even with a fixed exchange rate in the Common Monetary Policy simulation, which implies less volatility to consumers and fosters international trade. For the Hungarian economy, results are weaker, and it seems that Hungarian consumers are fairly indifferent between the monetary policy of their National Central Bank and the monetary policy of the ECB.

Detailed analysis of the results shows that the loss of monetary policy flexibility is more or less costly depending on several factors. The decision to enter is more costly when government shocks are important (for the Czech Republic and Poland), when technological shocks are important (for Hungary), and it also depends on the value of the import share between the countries under study and the EMU. Benefits of joining the EMU, for some countries, can arise from a more active monetary policy and if consumers have a strong preference for present consumption. The crosscountry correlation of technological and government consumption shocks are not very important to these countries' decisions.

The calculation of some benefits and other costs are excluded from our work, but the values found in this work for the costs of the loss of monetary policy flexibility are similar to the benefits associated with the disappearance of transaction costs calculated in other studies or the loss of seigniorage revenues found for the Hungarian case.

\section{Appendix}

\section{Appendix A - Data Specification and Results for Business Cycle Statistics}

Data were taken from the Quarterly National Accounts of NewCronos, an electronic database from EUROSTAT. The variables used are output (y), private consumption $(c)$, investment $(I)$, net exports as a percentage of GDP $(n x)$, all at constant prices, and employment $(l)$. We used quarterly data for the Czech Republic, Hungary, Poland, and the Eurozone at 15 Member Countries for the period between 1995:01 and 2007:04. $\mathrm{H}-\mathrm{P}$ filter was used to remove the trend and X-12 was used to remove seasonality, whenever data were not seasonally adjusted. All variables are in logarithms except net exports as a percentage of GDP. The cross-country correlations are for each of the three countries and the Eurozone. Results are presented in the second column of Tables $\mathrm{A} 1, \mathrm{~A} 2$, and $\mathrm{A} 3$. 
Table A1 - Statistics and Stylized Facts for the Czech Republic

\begin{tabular}{|c|c|c|c|}
\hline \multicolumn{5}{|c|}{ Data } & Common Monetary Policy & Autonomous Monetary Policy \\
\hline$Y$ & 1.31 & 1.31 & 1.31 \\
\hline$N X$ & 1.55 & 0.17 & 1.51 \\
\hline \multicolumn{5}{|c|}{ Standard Deviations Relative to GDP } \\
\hline$c$ & 1.42 & 0.48 & 0.66 \\
\hline$I$ & 3.71 & 2.96 & 3.88 \\
\hline$l$ & 0.72 & 1.79 & 2.20 \\
\hline \multicolumn{5}{|c|}{ Autocorrelations } \\
\hline$Y$ & 0.60 & 0.54 & 0.65 \\
\hline$c$ & 0.66 & 0.54 & 0.64 \\
\hline$I$ & 0.68 & 0.53 & 0.63 \\
\hline$l$ & 0.85 & 0.56 & 0.64 \\
\hline$N X$ & 0.65 & 0.73 & 0.61 \\
\hline \multicolumn{5}{|c|}{} & Cross-Country Correlations \\
\hline$\left(Y, Y^{*}\right)$ & 0.09 & 1.00 & 0.81 \\
\hline$\left(c, c^{*}\right)$ & -0.44 & 1.00 & -0.02 \\
\hline$\left(I, I^{*}\right)$ & -0.33 & 1.00 & -0.05 \\
\hline$\left(l, l^{*}\right)$ & -0.22 & 0.95 & 0.35 \\
\hline$(Y, N X)$ & -0.004 & 0.04 & 0.25 \\
\hline
\end{tabular}

Table A2 - Statistics and Stylized Facts for Hungary

\begin{tabular}{|c|c|c|c|}
\hline \multicolumn{5}{|c|}{ Data } & Common Monetary Policy & Autonomous Monetary Policy \\
\hline$Y$ & 0.81 & 0.81 & 0.81 \\
\hline$N X$ & 2.06 & 0.63 & 0.97 \\
\hline \multicolumn{5}{|c|}{ Standard Deviations Relative to GDP } \\
\hline$c$ & 2.82 & 0.57 & 0.69 \\
\hline$I$ & 8.07 & 2.49 & 3.18 \\
\hline$l$ & 0.99 & 2.91 & 3.05 \\
\hline \multicolumn{5}{|c|}{ Autocorrelations } \\
\hline$Y$ & 0.70 & 0.65 & 0.69 \\
\hline$c$ & 0.82 & 0.61 & 0.59 \\
\hline$I$ & 0.40 & 0.56 & 0.58 \\
\hline$l$ & 0.81 & 0.69 & 0.68 \\
\hline$N X$ & 0.41 & 0.75 & 0.66 \\
\hline \multicolumn{5}{|c|}{} & \multicolumn{3}{|c|}{ Cross-Country Correlations } \\
\hline$\left(Y, Y^{*}\right)$ & 0.23 & 0.65 & 0.60 \\
\hline$\left(c, c^{*}\right)$ & 0.02 & 0.96 & 0.05 \\
\hline$\left(I, I^{*}\right)$ & 0.26 & 0.98 & -0.11 \\
\hline$\left(l, l^{*}\right)$ & 0.62 & 0.30 & 0.18 \\
\hline$(Y, N X)$ & -0.27 & 0.37 & 0.29 \\
\hline
\end{tabular}


Table A3 - Statistics and Stylized Facts for Poland

\begin{tabular}{|c|c|c|c|}
\hline \multicolumn{5}{|c|}{ Data } & Common Monetary Policy & Autonomous Monetary Policy \\
\hline$Y$ & 1.36 & 1.36 & 1.36 \\
\hline$N X$ & 1.58 & 0.34 & 1.00 \\
\hline \multicolumn{5}{|c|}{ Standard Deviations Relative to GDP } \\
\hline$c$ & 0.76 & 0.38 & 0.50 \\
\hline$I$ & 5.18 & 3.70 & 4.88 \\
\hline$l$ & 1.15 & 2.03 & 2.10 \\
\hline \multicolumn{5}{|c|}{ Autocorrelations } \\
\hline$Y$ & 0.62 & 0.50 & 0.37 \\
\hline$c$ & 0.79 & 0.54 & 0.58 \\
\hline$I$ & 0.88 & 0.52 & 0.56 \\
\hline$l$ & 0.78 & 0.54 & 0.53 \\
\hline$N X$ & 0.30 & 0.00 & 0.13 \\
\hline \multicolumn{5}{|c|}{} & \multicolumn{3}{|c|}{ Cross-Country Correlations } \\
\hline$\left(Y, Y^{*}\right)$ & 0.35 & 0.92 & 0.36 \\
\hline$\left.\left(c, c^{*}\right\}\right)$ & -0.24 & 0.99 & -0.04 \\
\hline$\left(I, I^{*}\right)$ & 0.51 & 1.00 & -0.16 \\
\hline$\left(l, l^{*}\right)$ & -0.12 & 0.84 & 0.26 \\
\hline$(Y, N X)$ & -0.28 & 0.13 & -0.09 \\
\hline
\end{tabular}

\section{Appendix B - Additional Business Cycle Calculation}

The data were taken from AMECO database, an online annual database of the European Commission. We estimated an OLS regression based on the following expression:

$$
y_{-} c i c_{t}=\beta_{1} y_{-} c i c_{t-1}+\beta_{2} y_{-} c i c_{t-2}+\beta_{3} y_{-} c i c_{t}^{*}+\beta_{4} y_{-} c i c_{t-1}^{*}+\beta_{5} y_{-} c i c_{t-2}^{*}+\varepsilon_{t}
$$

where $y_{-}$cic is the cyclical component of real GDP of the domestic economy and $y_{-} c i c *$ is the cyclical component of real GDP of the foreign economy. $\varepsilon_{t}$ can be regarded as the idiosyncratic component of the domestic economy fluctuations, i.e., the part of the domestic economy cycle that is not explained by the Eurozone business cycle (or alternatively the USA) or by the past behaviour of the country cycle. The variables were detrended using H-P filter with a value of 100 . For each country we perform several estimations in order to achieve the best possible fit. This means that whenever variables were not statistically significant, they were removed.

Our purpose with these calculations is to determine the proportion of the business cycle explained by idiosyncratic shocks in each of the three countries. This proportion is calculated in the following way: $\frac{\sigma_{\varepsilon_{t}}}{\sigma_{y_{-} c i c_{t}}}$, where $\sigma_{\varepsilon_{t}}$ is the standard deviation of the idiosyncratic component of the cycle and $\sigma_{y_{-} c c_{t}}$ is the total standard deviation of the 
cycle in the domestic economy. Thus, the greater the value of this ratio, the greater the proportion of the business cycle that is due to specific country shocks. We also seek to compare the importance of the Eurozone and the USA in explaining the economic cycle of these countries, which is why we make two estimations for each country: one where the foreign economy is the Eurozone, and another where the foreign economy is the USA.

\section{Appendix C - The Benchmark Model}

\section{Consumers}

In each period $t=0,1, . ., N$ infinitely-lived consumers choose their allocations, facing the following budget constraint:

$$
\begin{gathered}
P_{t} c_{t}+M_{t}+E_{t+1} Q_{t} B_{t+1} \\
\leq P_{t} W_{t} l_{t}+M_{t-1}+T_{t}+Q_{t-1} B_{t}+\Pi_{t}
\end{gathered}
$$

where $\Pi_{t}$ represents profits of the home country intermediate goods producers and $W_{t}$ represents real wages. The initial conditions $M_{-1}$ and $B_{0}$ are given.

In this economy markets are complete, i.e., the asset structure is represented by having a set of government bonds, which represents a vector of state contingent securities. $Q_{t}$ is the vector of state contingent prices for the bonds. Consumers choose consumption, labour, real money balances, and bond holdings to maximize their utility:

$$
\mathrm{E}_{0} \sum_{\mathrm{t}=0}^{\infty} \beta^{t} U\left(c_{t}, l_{t}, M_{t} / P_{t}\right)
$$

subject to (19). The first-order conditions for the consumer are:

$$
\begin{gathered}
-\frac{U_{t}^{l}}{U_{t}^{c}}=W_{t} \\
\frac{U_{t}^{m}}{P_{t}}-\frac{U_{t}^{c}}{P_{t}}+\beta E_{t+1} \frac{U_{t}^{c}}{P_{t+1}}=0 \\
Q_{t-1}=\beta E_{t+1} \frac{U_{t}^{c}}{U_{t-1}^{c}} \frac{P_{t-1}}{P_{t}}
\end{gathered}
$$

where $U_{t}^{c}, U_{t}^{l}$, and $U_{t}^{m}$ are the derivatives of the variables of the utility function. We can define the nominal interest rate from the last first-order condition: $\frac{1}{1+r^{N}}=\beta E_{t+1} \frac{U_{t+1}^{c}}{U_{t}^{c}} \frac{P_{t}}{P_{t+1}}$. 


\section{Final Goods Producers}

In country $H$ non-tradable final goods are produced from intermediate goods through the following production function:

$$
y_{t}=\left[a_{1}\left(\int_{0}^{1}\left(y_{i, t}^{H}\right)^{\theta} d i\right)^{\frac{\rho}{\theta}}+a_{2}\left(\int_{0}^{1}\left(y_{i, t}^{F}\right)^{\theta} d i\right)^{\frac{\rho}{\theta}}\right]^{1 / \rho}
$$

where $y_{i, t}^{H}$ and $y_{i, t}^{F}$ are intermediate goods produced in $H$ and $F$, respectively. Parameter $\theta$ determines the mark-up of price over marginal $\operatorname{cost}(\theta$ is the elasticity of substitution between goods produced in the same country, representing the market power of producers), $\rho$ along with $\theta$ determine the elasticity of substitution between home and foreign goods. Parameters $a_{1}$ and $a_{2}$, combined with $\theta$ and $\rho$, determine the ratio of imports to output.

Final goods producers behave in a competitive way, in each period $t$, choosing inputs $y_{i, t}^{H}$ for $i \in[0,1]$ and $y_{i, t}^{F}$ for $i \in[0,1]$, and $y_{t}$ to maximize profits subject to (21). Prices are expressed in units of domestic currency. Price of intermediate goods can at most depend on $t-1$, because producers set prices before period $t$. Factor demand functions are calculated by the resolution of the maximization problem and have the following expressions:

$$
\begin{aligned}
& y_{i, t}^{H}=\frac{\left[a_{1} P_{t}\right]^{\frac{1}{1-\rho}} \stackrel{-}{P}_{t-1}^{H} \frac{\rho-\theta}{(1-\rho)(\theta-1)}}{\left(P_{i, t-1}^{H}\right)^{\frac{1}{1-\theta}}} y_{t} \\
& y_{i, t}^{F}=\frac{\left[a_{2} P_{t}\right]^{\frac{1}{1-\rho}} \stackrel{-}{P}_{t-1}^{\prime} \frac{\rho-\theta}{(1-\rho)(\theta-1)}}{\left(P_{i, t-1}^{F}\right)^{\frac{1}{1-\theta}}} y_{t}
\end{aligned}
$$

where $\stackrel{-H}{P}_{t-1}^{H}$ is the average price of inputs and is equal to: $\stackrel{-H}{P}_{t-1}^{H}=\left(\int_{0}^{1}\left(P_{i, t-1}^{H}\right)^{\frac{1}{1-\theta}} d i\right)^{\frac{\theta-1}{\theta}}$ and $\stackrel{-}{P_{t-1}}$ is equal to: $\stackrel{-}{P}_{t-1}^{F}=\left(\int_{0}^{1}\left(P_{i, t-1}^{F}\right)^{\frac{1}{1-\theta}} d i\right)^{\frac{\theta-1}{\theta}}$.

Since all producers behave competitively, their economic profit is zero, and the final good price is given by:

$$
P_{t}=\left(a_{1}^{\frac{1}{1-\rho}}\left({ }_{-}^{-H}\right)_{t-1}^{\frac{\rho}{\rho-1}}+a_{2}^{\frac{1}{1-\rho}}\left(\begin{array}{c}
-F \\
P_{t-1}
\end{array}\right)^{\frac{\rho}{\rho-1}}\right)
$$

which is independent of period $t$ shocks. 


\section{Intermediate Goods Producers}

Each tradable intermediate good $i$ is produced according to a standard constant returns to scale production function:

$$
y_{i, t}^{H}+y_{i, t}^{H^{*}}=F\left(k_{i, t-1}, A_{t} l_{i, t}\right)
$$

where $y_{i, t}^{H}$ and $y_{i, t}^{H^{*}}$ are the quantities of the intermediate goods produced in $H$ used in the production of the final good in country $H$ and $F$, respectively. The law of motion for capital is given by:

$$
k_{i, t}=(1-\delta) k_{i, t-1}+I_{i, t}-\varphi\left(\frac{I_{i, t}}{k_{i, t-1}}\right) k_{i, t-1}
$$

The initial capital stock $k_{i,-1}$ is given and is the same for all producers in this group. Intermediate producers behave as imperfect competitors, setting their prices in a staggered way. As usual, this monopolistic setting ensures that output is determined by demand, at least in the short term when prices are fixed. Specifically, at the beginning of each period $t$, a fraction $1 / N$ of producers in $H$ chooses a home currency price $P_{i, t-1}^{H}$ for the home market and a price for the foreign market. Intermediate goods prices are set in local market currency. As these prices are set for $N$ periods, for this group of intermediate goods producers: $P_{i, t+\tau-1}^{H}=P_{i, t-1}^{H}$ and $P_{i, t+\tau-1}^{H^{*}}=P_{i, t-1}^{H^{*}}$ for $\tau=0, \ldots, N-1$. Intermediate goods producers are indexed so that those with $i \in[0,1 / N]$ set prices in $0, N, 2 N$, and so on, while those with $i \in[1 / N, 2 / N]$ set prices in $1, N+1,2 N+1$, and so on, for the $N$ groups of intermediate producers. Once prices are set, each intermediate goods producer must satisfy his demand. Consider, for example, producers in a group, namely $i \in[0,1 / N]$, who choose prices $P_{i, t-1}^{H}$ and $P_{i, t-1}^{H^{*}}$, production factors $l_{i, t}, k_{i, t}$, and $I_{i, t}$ to solve the following problem:

$$
\max E_{0} \sum_{t=0}^{\infty} Q_{t}\left[P_{i, t-1}^{H} y_{i, t-1}^{H}+e_{t} P_{i, t-1}^{H^{*}} y_{i, t-1}^{H^{*}}-P_{t} W_{t} l_{i, t}-P_{t} I_{i, t}\right]
$$

subject to (25), (26), and the constraints that their supplies to home and foreign markets must equal the amount demanded by home and foreign final goods producers, from equation (22) and analog for $F$ (equation (23)). Another constraint implies that prices are set for $N$ periods. $e_{t}$ is the nominal exchange rate. Optimal prices for $t=0, N, 2 N$

and so on, are: $P_{i, t-1}^{H}=\frac{\sum_{\tau=t}^{t+N-1} E_{\tau} Q_{\tau} P_{\tau} v_{i, \tau} \Lambda_{\tau}^{H}}{\theta \sum_{\tau=t}^{t+N-1} E_{\tau} Q_{\tau} \Lambda_{\tau}^{H}}$ and $P_{i, t-1}^{H^{*}}=\frac{\sum_{\tau=t}^{t+N-1} E_{\tau} Q_{\tau} P_{\tau} v_{i, \tau} \Lambda_{\tau}^{H^{*}}}{\theta \sum_{\tau=t}^{t+N-1} E_{\tau} Q_{\tau} e_{\tau} \Lambda_{\tau}^{H^{*}}}$, where $v_{i, t}$

is equal to the wage rate divided by the marginal product of labour $\left(W_{t} / F_{i, t}^{l} A_{t}\right)$ and

$$
\Lambda_{\tau}^{H}=\left[a_{1} P_{t}\right]^{\frac{1}{1-\rho}}\left(\bar{P}_{t-1}^{H}\right)^{\frac{\rho-\theta}{(1-\rho)(\theta-1)}} y_{t} \text { and } \Lambda_{\tau}^{H}=\left[a_{1} P_{t}\right]^{\frac{1}{1-\rho}}\left(\begin{array}{c}
H \\
\bar{P}_{t-1}
\end{array}\right)^{\frac{\rho-\theta}{(1-\rho)(\theta-1)}} y_{t} .
$$


In a symmetric steady state real unit costs are equal across firms. Hence, in this steady state these formulas reduce to $P_{i,}{ }^{H}=P_{i}{ }^{*}=P v / \theta$, so that the law of one price holds for each good, and prices are set as a mark-up $(1 / \theta)$ over marginal costs $P v$.

\section{References}

Angeloni, I., Flad, M., Mongelli, F. P. (2005), "Economic and Monetary Integration of the New Member States - Helping to Chart the Route." ECB Occasional Paper Series No. 36.

Blanchard, O., Kahn, C. (1980), "The Solution of Linear Difference Models under Rational Expectations." Econometrica, Vol. 48, No. 5, pp. 1305-1311.

Brouwer, J., Paap, R., Viaene, J. M. (2008), “The Trade and FDI Effects of EMU Enlargement." Journal of International Money and Finance, Vol. 27, No. 2, pp. 188-208.

Bruha, J., Podpiera, J., Polák, S. (2010), "The Convergence Dynamics of a Transition Economy: The Case of the Czech Republic." Economic Modelling, Vol. 27, No. 1, pp. 116-124.

Carré, M., Collard, F. (2003), "Monetary Union: a Welfare Based Approach." European Economic Review, Vol. 47, No. 3, pp. 521-552.

Ca'Zorzi, M., Santis, R. A. de; Zampolli, F. (2012), "The Minimum Economic Dividend for Joining a Currency Union." German Economic Review, Vol. 13, No. 2, pp. 127-141.

Chari, V. V., Kehoe, P. J., McGrattan, E. R. (2002a), "Can Sticky Price Models Generate Volatile and Persistent Real Exchange Rates?" Review of Economic Studies, Vol. 69, No. 3, pp. 533-563.

Chari, V. V., Kehoe, P. J., McGrattan, E. R. (2002b), “Technical Appendix: Can Sticky Price Models Generate Volatile and Persistent Real Exchange Rates?” Federal Reserve Bank of Minneapolis, Research Department Staff Report 277.

Clarida, R., Gali, J., Gertler, M. (1999), "The Science of Monetary Policy: A New Keynesian Perspective." Journal of Economic Literature, Vol. 37, No. 4, pp. 1661-1707.

Clarida, R., Gali, J., Gertler, M. (2000), "Monetary Policy Rules and Macroeconomic Stability." The Quarterly Journal of Economics, Vol. 115, No. 1, pp. 147-180.

Cooley, T. F. (ed.) (1995), Frontiers of Business Cycles Research. Princeton: Princeton University Press.

Corsetti, G. (2008), "A Modern Reconsideration of the Theory of Optimal Currency Area." European Commission, Directorate-General for Economic and Financial Affairs, European Economy Economic Papers 308.

Csajbók, A., Csermely, Á. (eds.), (2002), "Adopting the Euro in Hungary: Expected Costs, Benefits and Timing." National Bank of Hungary Occasional Papers 24.

Czech National Bank (2012), "Analyses of the Czech Republic's Current Economic Alignment with the Euro Area 2012." Edited by Jakub Matějů \& Romana Zamazalová, Occasional Publications Edited Volumes, Czech National Bank, Monetary and Statistics Department, No. as12.

Domowitz, I., Hubbard, R. G., Petersen, B. C. (1986), "Business Cycles and the Relationship between Concentration and Price Cost-Margins." Rand Journal of Economics, Vol. 17, No. 1, pp. 1-18.

Fidrmuc; J., Korhonen, I. (2003), "Similarity of Supply and Demand Shocks Between the Euro Area and the CEECs." Economic Systems, Vol. 27, No. 3, pp. 313-334.

Frankel, J. A., Rose, A. K. (1998), "The Endogeneity of the Optimum Currency Area Criteria." Economic Journal, Vol. 108, No. 449, pp. 1009-1025.

Furceri, D., Karras, G. (2006), "Are the New Members Ready for the Euro? A Comparison of Costs and Benefits." Journal of Policy Modeling, Vol. 28, No. 1, pp. 25-38.

Gali, J., Gertler, M., Lopez-Salido, J. D. (2001), "European Inflation Dynamics." European Economic Review, Vol. 45, No. 7, pp. 1237-1270.

Goodfriend, M., King, R. G. (1997), "The New Neoclassical Synthesis and the Role of Monetary Policy." NBER Macroeconomics Annual, pp. 231-283. 
Hayo, B., Hoffman, B. (2006), "Comparing Monetary Policy Reactions Functions: ECB versus Bundesbank." Empirical Economics, Vol. 31, No. 3, pp. 645-662.

Holtemöller, O. (2007), "The Effects of Joining a Monetary Union on Output and Inflation Variability in Accession Countries." Mimeo.

Hurník, J., Tůma, Z., Vávra, D. (2010), "The Euro Adoption Debate Revisited: The Czech Case." Czech Journal of Economics and Finance (Finance a úvěr), Vol. 60, No. 3, pp. 194-212, Charles University Prague, Faculty of Social Sciences.

Jorgenson, D., Gollop, F., Fraumeni, B. (1987), Productivity and US Economic Growth. Cambridge, Massachusetts: MIT Press.

Kenen, P. (1969), "The Theory of Optimum Currency Areas: an Eclectic View." in: R. Mundell and A. K. Swoboda, eds., Monetary Problems of the International Economy. Chicago: University of Chicago Press, pp. 41-60.

Kolasa, M. (2009), "Structural Heterogeneity or Asymmetric Shocks? Poland and the Euro Area through the Lens of a Two-Country DSGE Model." Economic Modelling, Vol. 26, No. 6, pp. 1245-1269.

Lane, P. (2001), "The New Open Economy Macroeconomics: A Survey." Journal of International Economics, Vol. 54, No. 2, pp. 235-266.

Levasseur, S. (2008), "Updating Empirical Evidence on Business Cycles Synchronization between CEECs and the Euro Area: How Important is the Recent Period." Document de Travail No. 2008-11, April, OFCE.

Lucas Jr., R. (1987), Models of Business Cycles. Yrjö Jahnsson Lecture Series, Basil: Blackwell Publishers.

Mackinnon, R. I. (1963), "Optimum Currency Areas." American Economic Review, Vol. 53, No. 4, pp. 717-725.

Monacelli, T. (2000), "Relinquishing Monetary Policy Independence." Boston College Working Papers in Economics 483.

Mundell, R. (1961), "A Theory of Optimum Currency Areas." American Economic Review, Vol. 51, No. 4, pp. 657-665.

National Bank of Poland (2004), A Report on the Costs and Benefits of Poland's Adoption of the Euro. March.

Obstfeld, M., Rogoff, K. (1995), “Exchange Rate Dynamics Redux.” Journal of Political Economy, Vol. 103, No. 3, pp. 624-660.

Obstfeld, M., Rogoff, K. (1998), Foundations of International Macroeconomics. MIT Press.

Prescott, E. (1986), "Theory ahead of Business-Cycle Measurement." Carnegie-Rochester Conference Series on Public Policy, Vol. 25, No. 1, pp. 11-44.

Rose, A. K. (2000), "One Money, One Market: The Effect of Common Currencies on Trade." Economic Policy, Vol. 15, No. 30, pp. 7-46.

Sánchez, M. (2007), "Monetary Stabilisation in a Currency Union: The Role of Catching-Up Member States." Journal of Policy Modeling, Vol. 29, No. 1, pp. 29-40.

Sánchez, M. (2008), "Implications of Monetary Unions for Catching-Up Member States." Open Economies Review, Vol. 19, No. 3, pp. 371-390.

Taylor, J. B. (1993), "Discretion versus Policy Rules in Practice." Carnegie-Rochester Conference Series on Public Policy, Vol. 39, No. 1, pp. 195-214.

Whalley, J. (1985), Trade Liberalization among Major World Trading Areas. Cambridge, MA: MIT Press.

Wojcik, C. (2000), "A Critical Review of Unilateral Euroization Proposals: the Case of Poland." Focus on Transition 2, Austrian National Bank, pp. 48-76.

Woodford, M. (2003), Interest and Prices - Foundations of a Theory of Monetary Policy. Princeton: Princeton University Press.

Zienkowski, L. (2000), "Labor and Capital Productivity in Poland." Central Statistics Office, Poland. 